\title{
Genotoxicity assessment of titanium dioxide nanoparticle accumulation of 90 days in the liver of $g p t$ delta transgenic mice
}

Tetsuya Suzuki ${ }^{1,2}$, Nobuhiko Miura ${ }^{1,3}$, Rieko Hojo ${ }^{1}$, Yukie Yanagiba ${ }^{1}$, Megumi Suda ${ }^{1}$, Tatsuya Hasegawa ${ }^{4}$, Muneyuki Miyagawa ${ }^{1,5}$ and Rui-Sheng Wang ${ }^{1 *}$

\begin{abstract}
Backgound: A variety of in vivo and in vitro studies to assess the genotoxicity of titanium dioxide nanoparticles $\left(\mathrm{TiO}_{2} \mathrm{NPs}\right.$ ) have been reported, but the results are inconsistent. Recently, we reported that $\mathrm{TiO}_{2} \mathrm{NPs}$ exhibit no genotoxic effects in the liver and erythrocytes during a relatively brief period following intravenous injection into mice. However, there is no information about long-term genotoxicity due to $\mathrm{TiO}_{2} \mathrm{NP}$ accumulation in tissues. In this study, we investigated the long-term mutagenic effects of $\mathrm{TiO}_{2} \mathrm{NPs}$ and the localization of residual $\mathrm{TiO}_{2} \mathrm{NPs}$ in mouse liver after multiple intravenous injections.

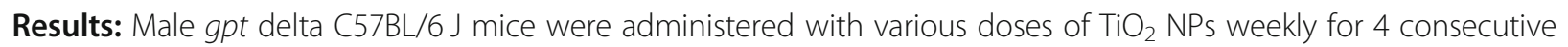
weeks. The long-term mutagenic effects on the liver were analyzed using gpt and $\mathrm{Spi}^{-}$mutation assays 90 days after the final injection. We also quantified the amount of titanium in the liver using inductively coupled plasma mass spectrometry and observed the localization of $\mathrm{TiO}_{2} \mathrm{NPs}$ in the liver using transmission electron microscopy. Although $\mathrm{TiO}_{2}$ NPs were found in the liver cells, the gpt and Spi ${ }^{-}$mutation frequencies in the liver were not significantly increased by the $\mathrm{TiO}_{2} \mathrm{NP}$ administration.
\end{abstract}

Conclusions: These results clearly show that $\mathrm{TiO}_{2} \mathrm{NPs}$ have no mutagenic effects on the liver, even though the particles remain in the liver long-term.

Keywords: Titanium dioxide, Nanoparticles, gpt delta mice, Mutation frequency

\section{Introduction}

Titanium dioxide nanoparticles $\left(\mathrm{TiO}_{2} \mathrm{NPs}\right)$ have become widely used in several industrial applications. Ultrafine $\mathrm{TiO}_{2}$ NPs $(10-50 \mathrm{~nm})$ cause lung cancer in rats through chronic inhalation [1]. Therefore, $\mathrm{TiO}_{2} \mathrm{NPs}$ are classified as an IARC Group 2B carcinogen (possibly carcinogenic to humans) [1,2]. Genotoxicity is one of the key factors to assess the carcinogenic risk to humans. Several studies in mice and rats have reported conflicting results of various genotoxic endpoint analyses [3-16]. Recently, we reported that $\mathrm{TiO}_{2}$ NPs have no genotoxic effects in the

\footnotetext{
* Correspondence: wang@h.jniosh.johas.go.jp

${ }^{1}$ Division of Industrial Toxicology and Health Effects Research, National Institute of Occupational Safety and Health, 6-21-1 Nagao, Tama-ku, Kawasaki, Kanagawa 214-8585, Japan

Full list of author information is available at the end of the article
}

liver and erythrocytes when intravenously injected into gpt delta mice [17], but there are still reports about their positive effect $[18,19]$. Thus, the genotoxicity of $\mathrm{TiO}_{2}$ NPs remains unclear [20, 21].

$\mathrm{TiO}_{2}$ NPs in the rodent bloodstream are translocated to the liver and remain in the tissue long-term [22-25]. However, the long-term genotoxic effects of $\mathrm{TiO}_{2} \mathrm{NPs}$ in the liver are not well understood. To investigate the long-term genotoxic effects, the mutagenicity is the optimum endpoint among various genotoxic endpoints because of the accumulation potential of $\mathrm{TiO}_{2} \mathrm{NPs}$. In this study, we examined the long-term mutagenicity of $\mathrm{TiO}_{2}$ NPs and the amount and localization of the remaining particles in the liver after intravenous injection in gpt delta mice [26]. Our results indicated that 
$\mathrm{TiO}_{2}$ NPs show no mutagenicity in the tissue, although they remain within the liver cells for an extended period of time.

\section{Materials and methods} Animals and reagents

The guidelines for the care and use of laboratory animals set forth by the Institutional Animal Care and Use Committee of the Japan National Institute of Occupational Safety and Health were followed. Male C57BL/6 J gpt delta mice were obtained from Japan SLC (Shizuoka, Japan). They were housed under specific pathogen-free conditions with a $12 \mathrm{~h}$ light-dark cycle and provided tap water and sterile CE-2 pellets (CLEA Japan Inc., Tokyo, Japan) ad libitum. Aeroxide ${ }^{\bullet}$ P25 titanium dioxide $\left(\mathrm{TiO}_{2}-\mathrm{P} 25\right)$ was purchased from Sigma-Aldrich (St. Louis, MO, USA).

\section{Preparation of the $\mathrm{TiO}_{2}$ NP suspension and its administration to mice}

The $\mathrm{TiO}_{2}-\mathrm{P} 25$ suspension was prepared as previously described [17]. Eight-week-old male gpt delta mice were randomly divided into four groups, with 6 mice per group. Mice were administrated by tail vein injection with the $\mathrm{TiO}_{2}-\mathrm{P} 25 \mathrm{NP}$ suspension at doses of 2,10 , and $50 \mathrm{mg} / \mathrm{kg}$ body weight once a week for 4 consecutive weeks. Mice were euthanized on day 90 after the final injection of $\mathrm{TiO}_{2}-\mathrm{P} 25$. Portions of the middle liver lobe were removed for gpt and $\mathrm{Spi}^{-}$mutation assays, quantification of titanium by inductively coupled plasma mass spectrometry (ICP-MS), and observation of $\mathrm{TiO}_{2}-\mathrm{P} 25$ particles by transmission electron microscopy (TEM).

\section{gpt and $\mathrm{Spi}^{-}$mutation assay}

The $g p t$ and $\mathrm{Spi}^{-}$mutation assays were conducted as previously described [17].

\section{Quantification of titanium in the liver by ICP-MS}

Liver samples were weighed and digested with nitric acid and hydrogen peroxide. The concentration of titanium in each sample was measured using ICP-MS (Agilent7900 ICP-MS, Agilent Technologies, Tokyo, Japan). The titanium concentration was determined at the mass number of $47 \mathrm{~m} / \mathrm{z}$ as previously reported [27].

\section{Observation of hepatocyte ultrastructure by TEM}

Liver samples taken at day 90 after the final injection of $\mathrm{TiO}_{2}$-P25 were analyzed using a JEM-2100F transmission electron microscope (JEOL, Tokyo, Japan) as previously described [17].

\section{Statistical analysis}

Statistical significance was examined using Dunnett's test after one-way ANOVA. Values of $P<0.05$ were considered significant.

\section{Results}

Characterization of $\mathrm{TiO}_{2}$ suspensions

$\mathrm{TiO}_{2}-\mathrm{P} 25$ was dispersed in disodium phosphate by sonication, as previously reported [17], then diluted to the concentration corresponding to each dose. The hydrodynamic sizes of $\mathrm{TiO}_{2}-\mathrm{P} 25$ in these diluents were measured each time before the injection by dynamic light scattering, and the average of four time determinations was showed in Table 1 . The $\mathrm{Z}$-average of the $\mathrm{TiO}_{2}-\mathrm{P} 25$ particles in suspension was about $150 \mathrm{~d} . \mathrm{nm}$, regardless of the different concentrations in these diluents.

\section{General observations of the animals}

The body weight of mice in each group did not differ at weekly measurement for the first 4 weeks and thereafter to the end of the experiment (data not shown). However, one mouse was dead immediately after the injection at the third week, but the cause for the death could not be identified. Some of the mice got astounded for a short time immediately after the injection, but the mice in all groups were basically not found with abnormal behaviors and appearance.

\section{Mutation frequencies of $\mathrm{gpt}$ and $\mathrm{Spi}^{-}$in the liver}

The $g p t$ and $\mathrm{Spi}^{-}$mutation frequencies in the liver were determined on day 90 after the last administration of $\mathrm{TiO}_{2}-\mathrm{P} 25$ (Tables 2 and 3). Either the gpt or $\mathrm{Spi}^{-}$mutation frequencies were not significantly different between the vehicle control group and $\mathrm{TiO}_{2}$ administration groups at any dose. These results suggest that $\mathrm{TiO}_{2}-\mathrm{P} 25$ has no mutagenic effect on hepatocytes in mice at $90 \mathrm{~d}$ after the last administration.

\section{Quantification and localization of $\mathrm{TiO}_{2} \mathrm{NPs}$ in the liver}

The amount of titanium in the liver of mice administered $\mathrm{TiO}_{2}-\mathrm{P} 25$ was quantified via ICP-MS. The average amount of titanium in the liver was dose dependent (Table 4). To clarify the localization of $\mathrm{TiO}_{2}$ particles, liver sections were obtained from mice treated with 50 $\mathrm{mg} / \mathrm{kg} \mathrm{TiO}_{2}-\mathrm{P} 25$, and the sections were observed by TEM. Large clusters containing the $\mathrm{TiO}_{2}$ NPs were found in the parenchymal hepatocytes (Fig. 1c) and Kupffer cells (Fig. 1d), although the clusters were much more prevalent in the latter. The particles were extremely agglomerated within the cytoplasm of both cell types. These results indicate that $\mathrm{TiO}_{2} \mathrm{NPs}$ remained in the liver $90 \mathrm{~d}$ after the last injection and were mainly localized in the cytoplasm of Kupffer cells. 
Table 1 Agglomeration sizes of different concentrations of $\mathrm{TiO}_{2}-\mathrm{P} 25$ suspensions in $2 \mathrm{mg} / \mathrm{mL}$ disodium phosphate

\begin{tabular}{llll}
\hline Concentration $(\mathrm{mg} / \mathrm{mL})$ & Dose $(\mathrm{mg} / \mathrm{kg} \mathrm{b.w.)}$ & Z-average $\left(\mathrm{d} . \mathrm{nm}^{\mathrm{a}}\right)$ mean $\pm \mathrm{SD}$ & $\mathrm{Pdl} \mathrm{mean}^{\mathrm{b}} \pm \mathrm{SD}$ \\
\hline 0.4 & 2 & $153.6 \pm 6.5$ & $0.168 \pm 0.03$ \\
2 & 10 & $152.6 \pm 7.2$ & $0.146 \pm 0.01$ \\
10 & 50 & $148.0 \pm 6.0$ & $0.172 \pm 0.01$ \\
\hline
\end{tabular}

${ }^{a}$ d.nm nm of diameter

${ }^{b} P d l$ Polydispersity index

\section{Discussion}

$\mathrm{TiO}_{2}$ NPs have been classified as an IARC Group 2B potential carcinogen. Therefore, their genotoxicity is an important property for risk assessment. Several in vivo studies related to genotoxic effects of $\mathrm{TiO}_{2} \mathrm{NPs}$ have been reported, but their results are inconsistent [3-17]. Almost all of these reports analyzed the micronuclei and DNA damage by the comet assay, which reveals transient genotoxic consequences that occur shortly after exposure. In addition, the mutagenicity in $\mathrm{TiO}_{2}$-accumulating tissues such as the liver and spleen has been examined in transgenic mice for a relatively brief period $[8$, 17]. Thus, the long-term mutagenic effects of $\mathrm{TiO}_{2} \mathrm{NPs}$

Table 2 The gpt mutation frequency in the livers of mice administered $\mathrm{TiO}_{2}-\mathrm{P} 2590$ days after the last administration

\begin{tabular}{|c|c|c|c|c|}
\hline \multirow{2}{*}{$\mathrm{TiO}_{2}-\mathrm{P} 25$} & \multirow{2}{*}{$\begin{array}{l}\text { Total } \\
\text { population }\end{array}$} & \multirow{2}{*}{$\begin{array}{l}\text { Number } \\
\text { of } \\
\text { mutations }\end{array}$} & \multicolumn{2}{|c|}{ Mutation frequency $\left(\times 10^{-6}\right)$} \\
\hline & & & & Mean \pm SD \\
\hline \multirow[t]{6}{*}{$0 \mathrm{mg} / \mathrm{kg}$} & $1,005,000$ & 1 & 1.00 & \\
\hline & $1,215,000$ & 5 & 4.12 & \\
\hline & 996,000 & 2 & 2.01 & \\
\hline & $1,242,000$ & 4 & 3.22 & \\
\hline & $1,074,000$ & 4 & 3.72 & \\
\hline & $1,530,000$ & 5 & 3.27 & $2.89 \pm 1.17$ \\
\hline \multirow[t]{6}{*}{$2 \mathrm{mg} / \mathrm{kg}$} & $1,065,000$ & 7 & 6.57 & \\
\hline & 468,000 & 8 & 17.09 & \\
\hline & $1,230,000$ & 4 & 3.25 & \\
\hline & $1,089,000$ & 1 & 0.92 & \\
\hline & $1,446,000$ & 4 & 2.77 & \\
\hline & $1,167,000$ & 6 & 5.14 & $5.96 \pm 5.80$ \\
\hline \multirow[t]{6}{*}{10 mg/kg } & 846,000 & 3 & 6.57 & \\
\hline & 912,000 & 5 & 3.55 & \\
\hline & 711,000 & 2 & 5.48 & \\
\hline & 771,000 & 4 & 2.81 & \\
\hline & $1,506,000$ & 2 & 5.19 & \\
\hline & $1,380,000$ & 5 & 1.33 & $3.66 \pm 1.54$ \\
\hline \multirow[t]{5}{*}{50 mg/kg } & 717,000 & 6 & 8.37 & \\
\hline & 552,000 & 5 & 9.06 & \\
\hline & 909,000 & 3 & 3.30 & \\
\hline & $1,011,000$ & 5 & 4.95 & \\
\hline & $1,314,000$ & 4 & 3.04 & $5.74 \pm 2.82$ \\
\hline
\end{tabular}

remain unclear. In this study, long-term genotoxic effects were examined in the liver of mice intravenously administered $\mathrm{TiO}_{2}$ NPs.

Recently, we reported that $\mathrm{TiO}_{2}-\mathrm{P} 25$ exhibits no mutagenicity in the liver of mice $9 \mathrm{~d}$ after the final injection based on gpt and $\mathrm{Spi}^{-}$mutation assays [17]. However, $\mathrm{TiO}_{2}$ NPs translocated to the liver are known to accumulate for a long period [22-25]. Thus, we have examined the mutagenicity of $\mathrm{TiO}_{2}-\mathrm{P} 25$ in the liver of longterm housed mice after the last administration. $\mathrm{TiO}_{2}$ P25 caused no mutagenic effects in the liver $90 \mathrm{~d}$ after the final injection, even though the particles were observed in the liver cells. The state of the cells that

Table 3 The Spi- mutant frequency in the livers of mice administered $\mathrm{TiO}_{2}-\mathrm{P} 2590 \mathrm{~d}$ after the last administration

\begin{tabular}{|c|c|c|c|c|}
\hline \multirow[t]{2}{*}{$\mathrm{TiO}_{2}-\mathrm{P} 25$} & \multirow{2}{*}{$\begin{array}{l}\text { Total } \\
\text { population }\end{array}$} & \multirow{2}{*}{$\begin{array}{l}\text { Number } \\
\text { of } \\
\text { mutants }\end{array}$} & \multicolumn{2}{|c|}{ Mutant frequency $\left(\times 10^{-5}\right)$} \\
\hline & & & & Mean \pm SD \\
\hline \multirow[t]{6}{*}{$0 \mathrm{mg} / \mathrm{kg}$} & $1,113,000$ & 14 & 1.26 & \\
\hline & $1,326,000$ & 20 & 1.51 & \\
\hline & 513,000 & 10 & 1.95 & \\
\hline & $1,185,000$ & 13 & 1.10 & \\
\hline & 951,000 & 24 & 2.52 & \\
\hline & $1,035,000$ & 14 & 1.35 & $1.61 \pm 0.53$ \\
\hline \multirow[t]{6}{*}{$2 \mathrm{mg} / \mathrm{kg}$} & 594,000 & 16 & 2.69 & \\
\hline & 972,000 & 17 & 1.75 & \\
\hline & 855,000 & 14 & 1.64 & \\
\hline & 774,000 & 13 & 1.68 & \\
\hline & $1,344,000$ & 33 & 2.46 & \\
\hline & $1,023,000$ & 20 & 1.96 & $2.03 \pm 0.43$ \\
\hline \multirow[t]{6}{*}{10 mg/kg } & 663,000 & 10 & 1.51 & \\
\hline & 738,000 & 10 & 1.36 & \\
\hline & $1,404,000$ & 16 & 1.14 & \\
\hline & $1,584,000$ & 17 & 1.07 & \\
\hline & $1,440,000$ & 80 & 5.56 & \\
\hline & 738,000 & 11 & 1.49 & $2.02 \pm 1.74$ \\
\hline \multirow[t]{5}{*}{$50 \mathrm{mg} / \mathrm{kg}$} & $1,332,000$ & 20 & 1.50 & \\
\hline & 345,000 & 1 & 0.29 & \\
\hline & $1,572,000$ & 14 & 0.89 & \\
\hline & $1,026,000$ & 17 & 1.66 & \\
\hline & 915,000 & 17 & 1.86 & $1.24 \pm 0.64$ \\
\hline
\end{tabular}


Table 4 The amount of titanium in the livers of mice administered $\mathrm{TiO}_{2}-\mathrm{P} 2590$ days after the last administration

\begin{tabular}{lll}
\hline $\mathrm{TiO}_{2}-\mathrm{P} 25$ & Analyzed no. of mice & Titanium $(\mu \mathrm{g} / \mathrm{g}$ tissue) \\
\hline $0 \mathrm{mg} / \mathrm{kg}$ & 6 & $0.10 \pm 0.05$ \\
$2 \mathrm{mg} / \mathrm{kg}$ & 6 & $6.9 \pm 4.1$ \\
$10 \mathrm{mg} / \mathrm{kg}$ & 6 & $16.0 \pm 4.0^{*}$ \\
$50 \mathrm{mg} / \mathrm{kg}$ & 5 & $24.4 \pm 9.1 *$ \\
\hline
\end{tabular}

The data are expressed as mean \pm SD

Statistical analysis was conducted by Dunnett's test; ${ }^{*} P<0.01$

incorporated $\mathrm{TiO}_{2}$ NPs after $90 \mathrm{~d}$ seemed mostly unchanged compared to that after $9 \mathrm{~d}$ [17]. In addition, the amount of titanium in the liver at $90 \mathrm{~d}$ after the last administration was similar to that at $9 \mathrm{~d}$ [17]. This result indicates that $\mathrm{TiO}_{2} \mathrm{NPs}$ are not easily removed from the liver, even after a long period, but their presence does not cause any adverse effects.
There were a few in vivo studies reported the positive genotoxic effect of $\mathrm{TiO}_{2}$-NPs. For example, $\mathrm{TiO}_{2}$ (Aeroxide $\mathrm{P} 25^{\circ}$ ) (same material as used in our present study) induced micronuclei and DNA strand breaks in peripheral blood in adult male mice exposed to $500 \mathrm{mg} / \mathrm{kg}$ $\mathrm{TiO}_{2}$ NPs of $21 \mathrm{~nm}$ size through drinking water for $5 \mathrm{~d}$ [14], but the effect was not analyzed in liver. With the same material and intravenous injection route, Dobrzynska et al [4] detected increase of micronuclei in bone marrow polychromatic erythrocytes of mice only at $24 \mathrm{~h}$ but not later at 7 and $28 \mathrm{~d}$. Modrzynska et al [28] investigated the DNA strand breaks in the liver of mice treated with $\mathrm{TiO}_{2}$ NPs (NanoAmor, $10.5 \mathrm{~nm}$ ) by intratracheal instillation, intravenous injection or oral gavage at a single dose of $162 \mu \mathrm{g} /$ mouse, and did not find DNA damages in liver tissue on day 1, 28 or 180 after the exposure by any administration routes, though there was a
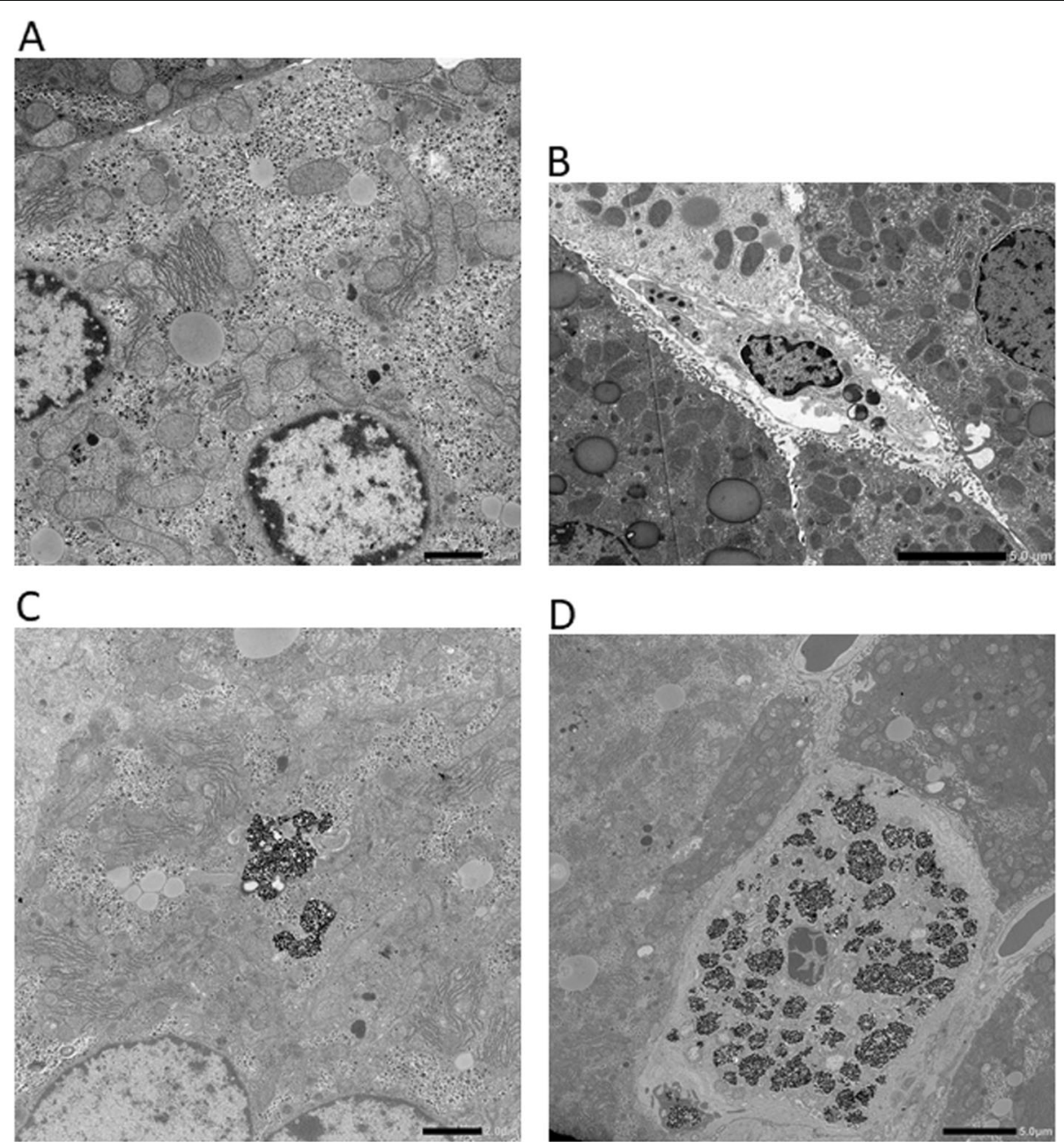

D

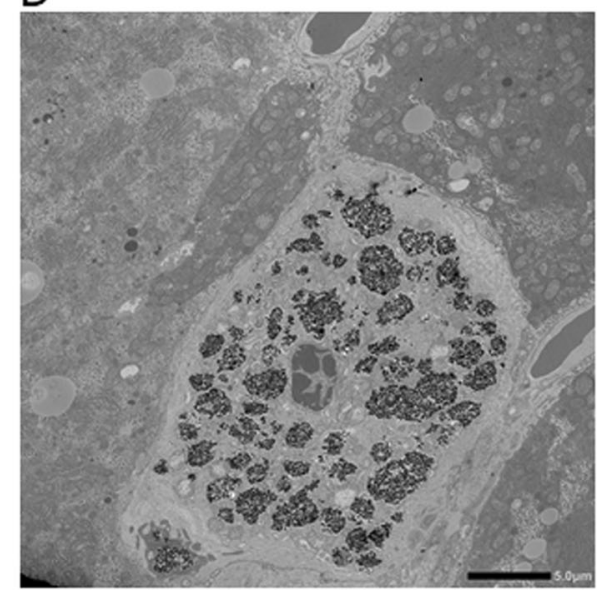

Fig. 1 Transmission electron microscope images of mice liver. $\mathbf{a}$ and $\mathbf{b}$, parenchymal hepatocyte and phagocyte, respectively, from the liver of control mice, and $\mathbf{c}$ and $\mathbf{d}$, parenchymal hepatocyte and phagocyte, respectively, from mice administered with $50 \mathrm{mg} / \mathrm{kg} \mathrm{TiO}_{2}-\mathrm{P} 25 .{ }^{*}$ Photo B was from a control mouse in the short period experiment with $\mathrm{TiO}_{2}-\mathrm{P} 25$ (Ref. no.17) 
significant increase in the level of DNA damages in lung tissue on day 180 following intratracheal instillation. These reports suggested that $\mathrm{TiO}_{2}$ NPs may induce transient DNA damages in tissue such as blood cells, but not in liver. The endpoint of genotoxicity in this study was gene mutations, which are basically not repairable and could indicate the long term effect. The negative findings in this study are supported by many other reports $[6-9,12,28]$. It is known that physicochemical characteristics (primary size, shape, etc.) and study designs (dose, dispersion method, recovery time, models) can influence the toxicity of nanoparticles in the assay system. More studies with different $\mathrm{TiO}_{2} \mathrm{NPs}$ are needed to better understand the health effects of this new material.

\section{Conclusion}

$\mathrm{TiO}_{2}$ NPs accumulate in the liver cells for long term. However, they do not induce genotoxic effect in the tissue. Therefore, the long-term genotoxic effects of $\mathrm{TiO}_{2}$ NPs administered by inhalation and ingestion which may introduce a small portion of the particles into liver, may be negligible in the liver.

\section{Acknowledgements}

We are deeply grateful to Dr. Masumura, Division of Genetics and Mutagenesis, National Institute of Health Sciences, Kawasaki, Japan, for providing the E. coli strains for gpt and Spi mutation assays.

\section{Authors' contributions}

TS, NM, RH, YY, MS, TH and RSW were involved in data collection. TS and RSW contributed to analyzing the data and drafting the manuscript. MM and RSW contributed to the data interpretation. All authors approved the final manuscript.

\section{Funding}

This study was funded by the National Institute of Occupational Safety and Health, Japan (N-P24-02).

\section{Availability of data and materials}

The datasets generated and /or analyzed during the current study are available from the corresponding author on reasonable request.

\section{Ethics approval}

The animal experiments was approved as stated in the "Animals and reagents".

\section{Consent for publication \\ Not applicable.}

\section{Competing interests}

The authors declare that they have no competing interests.

\section{Author details}

${ }^{1}$ Division of Industrial Toxicology and Health Effects Research, National Institute of Occupational Safety and Health, 6-21-1 Nagao, Tama-ku, Kawasaki, Kanagawa 214-8585, Japan. ${ }^{2}$ Present address: Graduate School of Biomedical and Health Sciences, Hiroshima University, Hiroshima 734-8553, Japan. ${ }^{3}$ Present Address: Department of Health Science, Yokohama University of Pharmacy, Yokohama 245-0066, Japan. ${ }^{4}$ Division of Human Environmental Science, Mount Fuji Research Institute, Yamanashi Prefectural Government, 5597-1 Kenmarubi, Kamiyoshida, Fujiyoshida, Yamanashi 403-0005, Japan. ${ }^{5}$ Present Address: Department of Sport and Medical Science, Faculty of Medical Technology, Teikyo University, Hachioji, Tokyo 192-0835, Japan.
Received: 24 October 2019 Accepted: 27 January 2020

Published online: 10 February 2020

\section{References}

1. Heinrich U, Fuhst R, Rittinghausen S, Creutzenberg O, Bellmann B, Koch W, Levsen K. Chronic inhalation exposure of Wistar rats and two different strains of mice to diesel engine exhaust, carbon black, and titanium dioxide. Inhal Toxicol. 1995;7:533-56.

2. IARC. IARC monographs on evaluation of carcinogenic risks to humans, carbon black, titanium dioxide, and talc, vol. 93. France: Lyon; 2010.

3. Chen Z, Wang Y, Ba T, Li Y, Pu J, Chen T, Song Y, Gu Y, Qian Q, Yang J, Jia G. Genotoxic evaluation of titanium dioxide nanoparticles in vivo and in vitro. Toxicol Lett. 2014:226:314-9.

4. Dobrzynska MM, Gajowik A, Radzikowska J, Lankoff A, Dusinska M, Kruszewski M. Genotoxicity of silver and titanium dioxide nanoparticles in bone marrow cells of rats in vivo. Toxicology. 2014;315:86-91.

5. Hwang YJ, Jeung YS, Seo MH, Yoon JY, Kim DK, Park JW, Han JH, Jeong SH. Asian dust and titanium dioxide particles-induced inflammation and oxidative DNA damage in C57BL/6 mice. Inhal Toxicol. 2010;22:1127-33.

6. Landsiedel R, Ma-Hock L, Van Ravenzwaay B, Schulz M, Wiench K, Champ S, Schulte S, Wohlleben W, Oesch F. Gene toxicity studies on titanium dioxide and zinc oxide nanomaterials used for UV-protection in cosmetic formulations. Nanotoxicology. 2010;4:364-81.

7. Lindberg HK, Falck GC, Catalan J, Koivisto AJ, Suhonen S, Jarventaus H, Rossi EM, Nykasenoja H, Peltonen Y, Moreno C, Alenius H, Tuomi T, Savolainen KM, Norppa H. Genotoxicity of inhaled nanosized TiO (2) in mice. Mutat Res. 2012;745:58-64.

8. Louro H, Tavares A, Vital N, Costa PM, Alverca E, Zwart E, de Jong WH, Fessard V, Lavinha J, Silva MJ. Integrated approach to the in vivo genotoxic effects of a titanium dioxide nanomaterial using LacZ plasmid-based transgenic mice. Environ Mol Mutagen. 2014;55:500-9.

9. Naya M, Kobayashi N, Ema M, Kasamoto S, Fukumuro M, Takami S, Nakajima M, Hayashi M, Nakanishi J. In vivo genotoxicity study of titanium dioxide nanoparticles using comet assay following intratracheal instillation in rats. Regul Toxicol Pharmacol. 2012;62:1-6.

10. Saber AT, Jacobsen NR, Mortensen A, Szarek J, Jackson P, Madsen AM, Jensen KA, Koponen IK, Brunborg G, Gutzkow KB, Vogel U, Wallin H. Nanotitanium dioxide toxicity in mouse lung is reduced in sanding dust from paint. Part Fibre Toxicol. 2012;9:4.

11. Saber AT, Jensen KA, Jacobsen NR, Birkedal R, Mikkelsen L, Moller $P$, Loft S, Wallin H, Vogel U. Inflammatory and genotoxic effects of nanoparticles designed for inclusion in paints and lacquers. Nanotoxicology. 2012;6:453-71.

12. Sadiq R, Bhalli JA, Yan J, Woodruff RS, Pearce MG, Li Y, Mustafa T, Watanabe F, Pack LM, Biris AS, Khan QM, Chen T. Genotoxicity of TiO (2) anatase nanoparticles in B6C3F1 male mice evaluated using pig-a and flow cytometric micronucleus assays. Mutat Res. 2012;745:65-72.

13. Sycheva LP, Zhurkov VS, lurchenko W, Daugel-Dauge NO, Kovalenko MA Krivtsova EK, Durnev AD. Investigation of genotoxic and cytotoxic effects of micro- and nanosized titanium dioxide in six organs of mice in vivo. Mutat Res. 2011;716:8-14.

14. Trouiller B, Reliene R, Westbrook A, Solaimani P, Schiestl RH. Titanium dioxide nanoparticles induce DNA damage and genetic instability in vivo in mice. Cancer Res. 2009;69:8784-9.

15. Donner EM, Myhre A, Brown SC, Boatman R, Warheit DB. In vivo micronucleus studies with 6 titanium dioxide materials (3 pigment-grade \& 3 nanoscale) in orally-exposed rats. Regul Toxicol Pharmacol. 2016;74:64-74.

16. Grissa I, Elghoul J, Ezzi L, Chakroun S, Kerkeni E, Hassine M, El Mir L, Mehdi $M$, Ben Cheikh $H$, Haouas Z. Anemia and genotoxicity induced by subchronic intragastric treatment of rats with titanium dioxide nanoparticles. Mutat Res Genet Toxicol Environ Mutagen. 2015;794:25-31.

17. Suzuki T, Miura N, Hojo R, Yanagiba Y, Suda M, Hasegawa H, Miyagawa M, Wang RS. Genotoxicity assessment of intravenously injected titanium dioxide nanoparticles in gpt delta transgenic mice. Mutat Res Genet Toxicol Environ Mutagen. 2016;802:30-7.

18. Kazimirova A, Baranokova M, Staruchova M, Drlickova M, Volkovova K, Dusinska M. Titanium dioxide nanoparticles tested for genotoxicity with the comet and micronucleus assays in vitro, ex vivo and in vivo. Mutat Res. 2019;843:57-65.

19. Gea M, Bonetta S, lannarelli L, Giovannozzi AM, Maurino V, Bonetta S, Hodoroaba VD, Armato C, Rossi AM, Schilirò T. Shape-engineered titanium 
dioxide nanoparticles (TiO2-NPs): cytotoxicity and genotoxicity in bronchial epithelial cells. Food Chem Toxicol. 2019;127:89-100.

20. Charles S, Jomini S, Fessard V, Bigorgne-Vizade E, Rousselle C, Michel C. Assessment of the in vitro genotoxicity of $\mathrm{TiO} 2$ nanoparticles in a regulatory context. Nanotoxicology. 2018;12:357-74.

21. Møller P, Jensen DM, Wils RS, Andersen MHG, Danielsen PH, Roursgaard M. Assessment of evidence for nanosized titanium dioxide-generated DNA strand breaks and oxidatively damaged DNA in cells and animal models. Nanotoxicology. 2017;11:1237-56.

22. Fabian E, Landsiedel R, Ma-Hock L, Wiench K, Wohlleben W, van Ravenzwaay B. Tissue distribution and toxicity of intravenously administered titanium dioxide nanoparticles in rats. Arch Toxicol. 2008;82:151-7.

23. Sugibayashi K, Todo H, Kimura E. Safety evaluation of titanium dioxide nanoparticles by their absorption and elimination profiles. J Toxicol Sci. 2008;33:293-8.

24. Umbreit TH, Francke-Carroll S, Weaver UL, Miller TJ, Goering PL, Sadrieh N, Stratmeyer ME. Tissue distribution and histopathological effects of titanium dioxide nanoparticles after intravenous or subcutaneous injection in mice. J Appl Toxicol. 2012;32:350-7.

25. Xie G, Wang C, Sun J, Zhong G. Tissue distribution and excretion of intravenously administered titanium dioxide nanoparticles. Toxicol Lett. 2011;205:55-61.

26. Nohmi T, Katoh M, Suzuki H, Matsui M, Yamada M, Watanabe M, Suzuki M, Horiya N, Ueda O, Shibuya T, Ikeda H, Sofuni T. A new transgenic mouse mutagenesis test system using Spi- and 6-thioguanine selections. Environ Mol Mutagen. 1996;28:465-70.

27. Miura N, Ohtani K, Hasegawa T, Yoshioka H, Hwang GW. High sensitivity of testicular function to titanium nanoparticles. J Toxicol Sci. 2017:42:359-66.

28. Modrzynska J, Berthing T, Ravn-Haren G, Jacobsen NR, Weydahl IK, Loeschner K, Mortensen A, Saber AT, Vogel U. Primary genotoxicity in the liver following pulmonary exposure to carbon black nanoparticles in mice. Part Fibre Toxicol. 2018;15:2-13.

\section{Publisher's Note}

Springer Nature remains neutral with regard to jurisdictional claims in published maps and institutional affiliations.

Ready to submit your research? Choose BMC and benefit from:

- fast, convenient online submission

- thorough peer review by experienced researchers in your field

- rapid publication on acceptance

- support for research data, including large and complex data types

- gold Open Access which fosters wider collaboration and increased citations

- maximum visibility for your research: over $100 \mathrm{M}$ website views per year

At $\mathrm{BMC}$, research is always in progress.

Learn more biomedcentral.com/submissions 